\title{
Habitat selection of the Common Quail (Coturnix coturnix) in an intensively managed agricultural environment
}

\author{
Tamás Márton NÉMeth ${ }^{1 *}$, Petra Kelemen ${ }^{2}$, Ágnes CsiszÁR ${ }^{3}$, Gyula \\ KovÁCs ${ }^{2}$, Sándor FARAGÓ ${ }^{2} \&$ Dániel WinkLeR ${ }^{2}$
}

Received: November 11, 2018 -Revised: December 13, 2018 -Accepted: December 14, 2018.

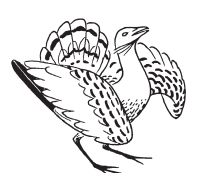

Németh, T. M., Kelemen, P., Csiszár, Á., Kovács, Gy., Faragó, S. \& Winkler, D. 2019. Habitat selection of the Common Quail (Coturnix coturnix) in an intensively managed agricultural environment. - Ornis Hungarica 27(1): 99-109. DOI: 10.2478/orhu-2019-0006

during the breeding season of 2014 in an intensively managed aricultural environment (LAJTA Project, NorthWest Hungary). In order to assess the habitat preferences of the Common Quail, habitat composition around occupied plots were compared with unoccupied control plots. To characterize the habitat, a total of 11 variables related to vegetation structure and diversity, food availability and landscape were quantified. Multivariate methods (PCA and GLMs) were used to distinguish the main factors influencing habitat selection and to model the presence of the Common Quail. Based on our results, in the LAJTA Project, high probability of Common Quail presence can be predicted in plots with higher herbaceous cover and more abundant arthropod communities. The network of ecotone habitats, particularly the proximity to woody habitats, also appeared to have significant importance during the breeding season.

Keywords: Common Quail, plant cover, food availability, field margin, forest belt

Összefoglalás Kutatásunkban a fürj (Coturnix coturnix) élőhelyválasztását vizsgáltuk intenzív agrárkörnyezetben (LAJTA Project), fészkelési időszakban, 2014-ben. Az élőhely jellemzéséhez a növényzet struktúrájára, az ízeltlábú táplálékkínálatra és a tájszerkezetre vonatkozó változókat számszerủsítettünk. A fürj élőhely-preferenciáinak értékelésére a tényleges territóriumok mellett random kontroll pontok felmérését is elvégeztük, az esetleges elkülönülést és az elkülönülést okozó változókat többváltozós statisztikai módszerekkel (PCA, GLMs) elemeztük. Vizsgálataink alapján a LAJTA Projectben a fürj jelenléte az olyan, erdősávoktól távolabb eső nyílt területeken valószínüsíthető, ahol magasabb a növényborítás és ízeltlábú abundancia. Az ökotonhálózat, ezen belül különösen az erdősávok nem elhanyagolható jelentőségüek.

Kulcsszavak: fürj, növényborítás, táplálékkínálat, táblaszegély, erdősáv

\footnotetext{
${ }^{1}$ Forest Research Institute, Department of Ecology and Silviculture, 9400 Sopron, Paprét 17., Hungary

${ }^{2}$ University of Sopron, Institute of Wildlife Management and Vertebrate Zoology, 9400 Sopron, Bajcsy-Zsilinszky utca 4., Hungary

${ }^{3}$ University of Sopron, Institute of Botany and Nature Conservation, 9400 Sopron, Bajcsy-Zsilinszky utca 4., Hungary

*corresponding author: nemeth.tmarton@erti.hu
} 


\section{Introduction}

Understanding the relationships between species and their habitat is a central question in ecology. Habitat defines the available range of resources and living conditions for a species, thus habitat has an important impact on vital rates, such as survival and reproduction (Hall et al. 1997). The aim of most habitat selection studies is to understand the roles of different factors, which determine the spatial distribution of individuals (Morris 2003). These diverse components of habitat selection patterns include for example the distribution and availability of food resources, available space (Morris \& Davidson 2000), or both intra- and interspecific interactions (Rosenzweig 1981, Morris 1999). Sometimes, however, individuals can only occupy habitats of lesser quality (Morris 2003). This often happens when the coverage of the suitable habitat is limited due to complete habitat loss or habitat fragmentation. It is widely known that agricultural intensification is one of the main reasons of the decline of farmland bird populations across Europe (e.g. Chamberlain \& Fuller 2000, Donald et al. 2001, 2006, Báldi 2008, Voříšek et al. 2010). However, regional differences in the degree of decline are recognized (Wretenberg et al. 2006, Báldi \& Faragó 2007, Báldi \& Batáry 2011, Tryjanowski et al. 2011); therefore more specific population studies are required to better understand the processes. Furthermore, some farmland birds have more habitat flexibility i.e. nesting site or foraging requirements, which could change the patterns of the bird population in the given region (Fuller 2012).

The Common Quail (Coturnix coturnix) is widely distributed throughout the Palaearctic region and it is the only long-distance migratory species of Phasianidae (Cramp 1980, McGowan et al. 1994). The Common Quail is a typical species of grassland areas, primarily prefers open land, usually without shrubs and trees, either in lowlands or in the mountainous regions. Due to habitat transformations associated with agricultural development, this species became one of the typical species of farmland breeders (Udvardy 1941, George 1990, Guyomarc'h et al. 1998). Until the early 1900s, the Common Quail was a common species in Europe, although a slight population decrease was already observed at the end of the $19^{\text {th }}$ century (Glutz von Blotzheim et al. 1994). In the 1980s, a large decline in its West-European population was observed (Perennou 2009) and has continued to show a declining trend in most European countries (BirdLife International 2018). In Hungary, the Common Quail is a protected species showing moderate population decline both locally and nationwide (Szép et al. 2012, Németh et al. 2014, MME 2018). The breeding population is estimated between 74,000 and 90,000 pairs (Hadarics \& Zalai 2008, BirdLife International 2018). Studies on Common Quail were mainly carried out in Western Europe (France, Germany, Spain), which were related to its habitat use, movements, hybridization with Japanese Quail (Coturnix japonica) or population distribution (e.g. Saint-Jalme \& Guyomarc'h 1989, George 1990, 1996, Guyomarc'h 2003, Puigcerver et al. 1999, 2007). Common Quail is a less studied species in Hungary, research on its ecology is poorly represented in the Hungarian avian literature (i.e. Keve et al. 1953), while mostly faunistic papers have been published (e.g. Szüts 1898, Barthos 1917, Külley 1924, Bán \& Igmándy 1939, Keve 1955, Rapos 1957, Kovács 1965, Debreceni et al. 1990, Kovács 2005, Faragó 2012b). 
The main goal of this study was to assess the habitat selection of the Common Quail in a human-transformed habitat. Our aim was to find out which parameters influence the habitat selection the most in an intensively managed agricultural environment.

\section{Material and Methods}

\section{Study area}

The study was carried out in the area of the LAJTA Project, which covers 3,065 ha of land in the Kisalföld (Little Hungarian Plain), North-West Hungary (Figure 1). Until 1995, the area had been managed exclusively by the Lajta-Hanság Co. However, in 1995, due to compensations/privatization, $50 \%$ of the area was transferred to the hands of smallholders. This area has a continental climate (mean annual temperature is $9.6^{\circ} \mathrm{C}$, annual precipitation is $504 \mathrm{~mm}$, mean relative humidity is $73 \%$ ) where mainly cereals, corn, alfalfa, rape and maize are cultivated. About $94 \%$ of the farming is large scale (Lajta-Hanság Joint Stock Company, average field size $40 \mathrm{ha}$ ) and $6 \%$ is small scale (small holders, average field size $2.5 \mathrm{ha}$ ). In both cases, there is intensive technology which, from the point of view of mechanization and the use of chemicals, has not changed in the past few decades. Fields are separated from each other by forest belts (110 ha), tree rows ( 8 ha) and hedgerows (1 ha) (Faragó 2012a). Pasturing did not take place in the Project territory and the fodder demand of animal husbandry was supplied by growing alfalfa and silo maize.

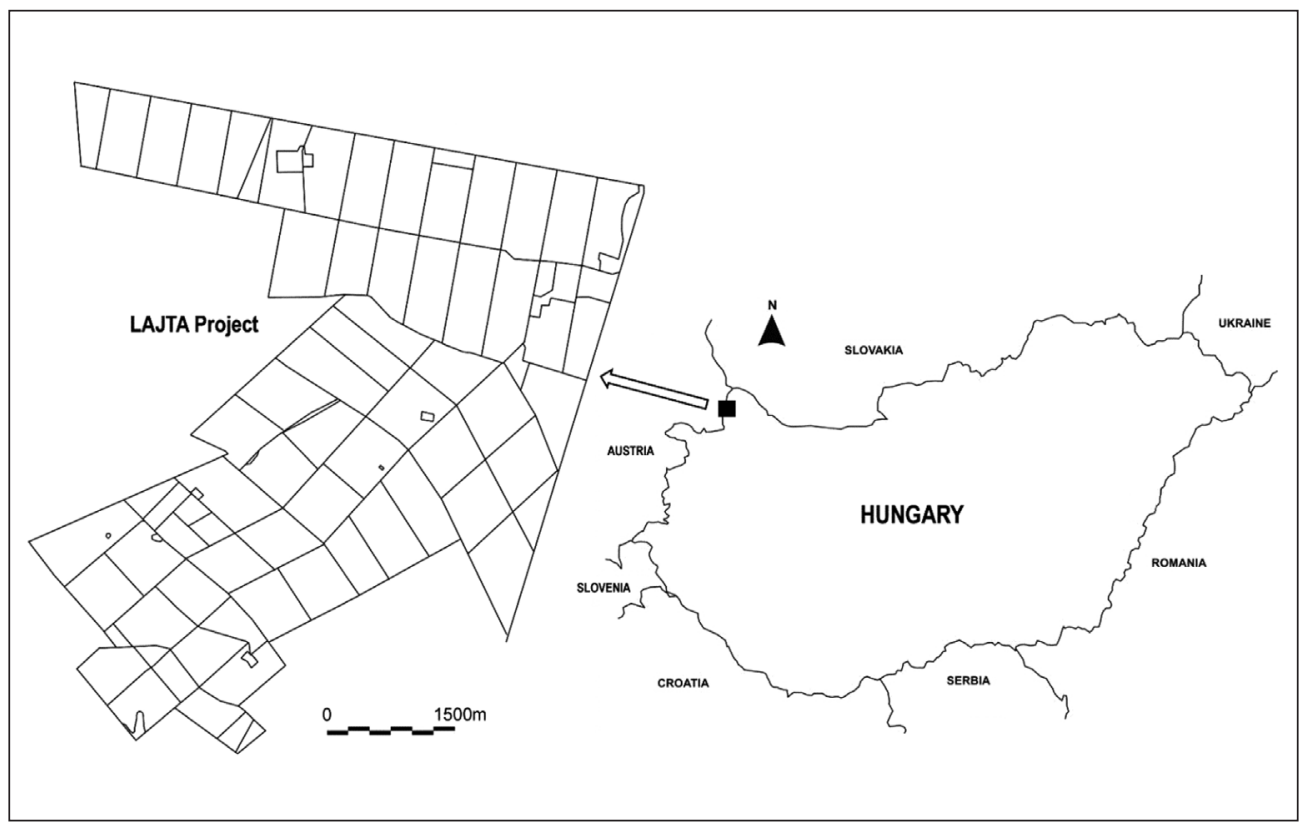

Figure 1. Map of the study area (LAJTA Project)

1.ábra A vizsgálati terület (LAJTA project) 


\section{Field surveys}

In Hungary, no specific survey technique has been proposed for the Common Quail, the used survey method is therefore roughly based on the guidance provided by Rodríguez-Teijeiro et al. (2010). Calling Common Quail males were counted during the breeding season between late April and August (28 survey days in total, 11 of which were in the beginning of the breeding season) in the entire study area by listening to the calls and crowing of the territory holding males. Surveys were carried out under favourable weather conditions, starting at dawn and lasting about 2.5-3 hours. At every survey point, during the first two minutes of stay we detected and counted the number of singing males. After this first step of detection, a digital bird caller (model NEWGOOD Speaker-92A) was used to play the female call lasting 20-25 seconds to stimulate silent males. The approximate position of each detected males were recorded by walking in the direction of the singing male until the bird rose up. The place from where quails delivered their first spontaneous calls at dusk has been regarded as the centre of activity. We considered a territory occupied if we documented multiple detections.

In order to assess the habitat preferences of the Common Quail, habitat composition for a total of 18 occupied territories were compared with 18 unoccupied control plots randomly selected in the study area. To characterize the habitat around territories, a total of 11 variables were quantified related to vegetation structure and diversity, food availability and landscape. Since the core daily activity area was described as a 1.5-2 ha (Perennou 2009), a 75 $\mathrm{m}$ radius plot was chosen for the determination of the following variables: plant species richness (Plant_S), plant diversity (Plant_Div), plant cover (Plant_Cov), arthropod number (Arth_N), arthropod dry weight (Arth_W) and arthropod diversity (Arth_Div). Furthermore, a $500 \mathrm{~m}$ radius plot was chosen to account for the following landscape characteristics: total length of woody ecotones like forest belts, tree rows, hedgerows (Wood_Lgth) and distance from the nearest one (Wood_Dist), total length of grassy field margins (Margin_Lgth) and distance from the nearest one (Margin_Dist); and total length of roads (Road_Lgth). With respect to grassy field margins, only those that appeared separately from woody ecotones were considered. For botanical analysis, species list and cover were recorded in randomly selected $5 \times 5 \mathrm{~m}$ quadrats $(\mathrm{N}=5)$. For measuring arthropod food availability, pitfall trapping was conducted. In each quadrat, a Barber trap (plastic cup of $300 \mathrm{ml}$ capacity, with $80 \mathrm{~mm}$ diameter and $120 \mathrm{~mm}$ depth) was placed fitted with aluminium roofs to prevent trapping small vertebrates (e.g. lizards, rodents, shrews). For preserving solution 5\% formaldehyde was used. Barber traps were installed following the detection and localization of the quails, and were operated for two months, roughly covering both the incubation and rearing periods. Traps were emptied in every two weeks.

\section{Data analysis}

Principal Component Analysis (PCA) was used to describe the habitat structure based on data of both the Common Quail occupied and non-occupied control plots and to distinguish the main factors influencing habitat selection. Only PCA factors with eigenvalues more than 1.0 
were selected (Kaiser Criterion). Factor loadings were rotated with a varimax raw transformation. Mean factor scores between the occupied and control plots were compared by using $t$-test. Normality and homogeneity of variances were tested for all parameters, and in case of necessity, transformed to fit the assumptions of parametric tests.

Generalized linear models (GLMs) were used to evaluate the presence of Common Quails, based on the obtained principal components (PCs). Since territory occupation by quails was considered as a binary response variable (presence -1 , absence -0 ), the logistic link functions was applied with binomial error structure. Forward stepwise (likelihood ratio) method was applied to select the final variable in the model. Each variable was tested for significance and only those contributing significantly $(p<0.05)$ to the model were retained. The performance of the GLMs was assessed using Cohen's Kappa statistics, describing the proportion of the correctly classified predictions after the probability of chance agreement has been removed (Cohen 1960). According to Landis and Koch (1977), strength of agreement can be considered slight to fair for $\kappa$ values $0-0.4$, moderate for $0.4-0.6$, substantial for $0.6-$ 0.8 and almost perfect for $0.8-1.0$, respectively. Statistical analyses were computed using SPSS ver. 20 (IBM Corp. Released, 2011) and SAS statistical package ver. 9.1 (SAS 2012).

\section{Results}

The PCA performed on the habitat variables yielded four new variables with eigenvalues higher than 1.0 that together explain $87.85 \%$ of the total variance (Table 1). The first component (PC1) accounted for $36.85 \%$ of the total variance and it is principally governed by variables connected with herbaceous cover (Plant_Cov) and diversities (Plant_S, Plant_Div). Other major contributors to $\mathrm{PC1}$ are the abundance of arthropods (Arth_N) and distance from the nearest woody ecotone (Wood Dist). Mean factor scores on this axis differ significantly between the Common Quail occupied and non-occupied control plots ( $t$ test, $t=5.023, \mathrm{p}<0.01$ ). The second component (PC2) accounted for $22.36 \%$ of the total
Table 1. Factor loadings after varimax rotation for the principal components in PCA on the habitat variables used

1. táblázat Az élőhelyváltozókon végzett fökomponens analízis (PCA) eredménye: komponens-együtthatók mátrixa varimax forgatás után

\begin{tabular}{|l|l|l|l|l|}
\hline \multirow{2}{*}{} & \multicolumn{4}{|c|}{ Principal component } \\
\cline { 2 - 5 } & $\mathbf{P C 1}$ & \multicolumn{1}{|c|}{ PC2 } & PC3 & \multicolumn{1}{c|}{ PC4 } \\
\hline Plant_S & $\mathbf{0 . 5 1 4}$ & 0.183 & 0.319 & 0.264 \\
\hline Plant_Div & $\mathbf{0 . 6 0 3}$ & -0.098 & 0.290 & -0.119 \\
\hline Plant_Cov & $\mathbf{0 . 8 6 3}$ & 0.244 & -0.180 & 0.096 \\
\hline Arth_N & $\mathbf{0 . 6 6 7}$ & 0.340 & -0.187 & 0.022 \\
\hline Arth_W & -0.231 & $\mathbf{0 . 8 0 1}$ & -0.196 & -0.231 \\
\hline Arth_Div & -0.214 & $\mathbf{0 . 8 7 0}$ & 0.144 & 0.097 \\
\hline Wood_Lgth & 0.311 & -0.372 & $\mathbf{0 . 7 9 6}$ & 0.159 \\
\hline Wood_Dist & $-\mathbf{0 . 6 9 6}$ & -0.313 & 0.134 & 0.221 \\
\hline Margin_Lgth & 0.319 & $\mathbf{0 . 5 7 6}$ & 0.276 & -0.202 \\
\hline Margin_Dist & -0.361 & -0.344 & $-\mathbf{0 . 6 2 5}$ & -0.033 \\
\hline Road_Lgth & 0.193 & -0.209 & 0.220 & $-\mathbf{0 . 6 7 8}$ \\
\hline Eigenvalues & 4.054 & 2.460 & 1.920 & 1.229 \\
\hline Explained variance \% & 36.85 & 22.36 & 17.46 & 11.17 \\
\hline Cumulated variance \% & 36.85 & 59.22 & 76.68 & 87.85 \\
\hline
\end{tabular}


variance, with loadings large for arthropod diversity (Arth_Div) and weight (Arth_W); and total length of field margins (Margin Lgth). On this axis, no significant difference has been observed between the mean factor scores of occupied and control plots ( $t$ test, $t=0.892$, NS). The third component (PC3), accounted for an ad-
Table 1. Summary of GLMs for the probability of presence of Common Quail

2. táblázat Az általánosított lineáris modell (GLMs) eredménye a fürj jelenlétének predikciójára

\begin{tabular}{|l|l|l|l|l|}
\hline \multicolumn{1}{|c|}{ Factors } & \multicolumn{1}{c|}{$\boldsymbol{\beta}$} & \multicolumn{1}{c|}{ SE } & \multicolumn{1}{c|}{$\boldsymbol{X}^{\mathbf{2}}$} & \multicolumn{1}{c|}{$\boldsymbol{p}$} \\
\hline (intercept) & 2.018 & 0.747 & 7.114 & 0.008 \\
\hline PC1 & 0.076 & 0.017 & 34.073 & 0.000 \\
\hline PC3 & -0.625 & 0.210 & 3.988 & 0.047 \\
\hline Residual deviance & 17.963 & & & \\
\hline
\end{tabular}

ditional $17.46 \%$ of the total variance, is determined by the woody ecotone length (Wood Lgth) and distance from the nearest field margin (Margin_Dist). No significant difference was observed among the Common Quail and control plots on this axis ( $t$ test, $t=1.873$, NS). The fourth component (PC4), accounted for $11.17 \%$ of the total variance, was mainly governed by the total length of roads (Road_Lgth). Nevertheless, mean factor scores showed no significant difference on this axis ( $t$ test, $t=1.516, \mathrm{NS})$.

A summary of the final GLM model is presented in Table 2. PC1 showed a positive influence $(\beta=0.076)$ on Common Quail presence probability, and it was the most influential new variable $\left(\chi^{2}=34.073\right)$ derived from the PCA. PC3 was less influential $\left(\chi^{2}=3.988\right)$ and showed a negative relationship ( $\beta=-0.625)$ to the presence probability of quails. The model performed better in correctly predicting Common Quail habitat where presence occurred (70.4\%) than in correctly classifying unoccupied habitat (62.6\%). According to the $\kappa$ statistic $(0.341)$ the model had only fair agreement with the testing dataset.

\section{Discussion}

In Hungary, the Common Quail once inhabited grasslands and wooded steppes (Faragó 2002). Nowadays, significant part of the population is breeding in agricultural environments, systematically choosing open land (Németh et al. 2014), usually preferring areas with a dense herb layer (Perennou 2009). Based on our results, in the LAJTA Project, two key components of the environment that positively affected the occurrence of Common Quails were protective cover and food availability. This dual requirement has been shown to be equally important for several other farmland bird species including the Grey Partridge (Perdix perdix) or Eurasian Skylark (Alauda arvensis). The dense herbaceous cover provides nesting site, more protection against rough weather conditions and predators (Rands 1986, Green \& Stowe 1993, Eggers et al. 2011). According to Capdevila et al. (2016), plant height may also have importance because taller vegetation has better suitability for hiding nests from predators. This is also demonstrated by the fact that in the course of crop harvesting the Common Quail moves to new, more suitable habitats with taller vegetation, as demonstrated by Rodríguez-Teijeiro et al. (2010) and Németh and Winkler (2017). As previously reported, the Common Quail did not avoid large arable fields with permanent crops (George 1990, Michailov 1995, Broyer 1996, Aunins \& Priednieks 2003). Moreby 
and Aebischer (1992) and Panek (1997) supposed that permanent cover tends to increase the number of insects, which is an essential food supply for gamebird chicks (e.g. partridges, quails) and maintains higher reproductive success of birds. Our results showed that arthropod abundance plays a crucial role in habitat selection, while diversity and biomass of arthropod prey seem to have less importance. Although seasonal variations occur in the diet of quails (Gál \& Marosán 2003), invertebrate species represent a significant proportion of Common Quail food during the breeding season (Keve et al. 1953, Combreau \& Guyomarc'h 1992). During the first few weeks after hatching, the chicks are feeding mainly on insects therefore growth is mainly determined by the available invertebrate food resources (Combreau \& Guyomarc'h 1989, Guyomarc'h et al. 1998). As the Common Quails also feeds on a wide range of seeds, apart from the plant cover the diversity of herbaceous vegetation seems to have great importance in the LAJTA Project, as indicated by the results of PCA. Managed cereal field, where the most Common Quail territories were found, usually support lower seed resources than field margins (Wilson et al. 1999, Vickery et al. 2002, Holland et al. 2012). Nevertheless, some cultivated fields (e.g. winter wheat, phacelia) in the LAJTA Project are characterized by considerable herbaceous cover and species richness, not reaching, however the conditions observed in the field margins. In our study, we found only slight effect of field margins. Capdevila et al. (2016) found that female quails preferred to nest near field margins, which might be related to the greater food resources and more suitable nest cover. Although a number of studies have emphasized the higher probability of predation risk in field margins (e.g. Paton 1994, Batáry \& Báldi 2004), Capdevila et al. (2016) found no edge effect in Common Quail nest predation probability. Apart from grassy strips, previous studies in Europe emphasized the role of woody ecotones (e.g. hedges, shrubs, forest shelterbelts) in relation to certain farmland birds (e.g. Jánoska 1998, Hinsley \& Bellamy 2000, Batáry et al. 2010, Faragó et al. 2012, Morelli 2013). In the LAJTA Project, the network of woody ecotones proved to have a non-negligible impact on Common Quail habitat selection through breaking the continuity of large fields. As the results revealed, the Common Quail showed avoidance of the forest belts and was mainly detected far from their edges, which is in good agreement with observations conducted in similar environments (e.g. Panek 1998, Perennou 2009).

Our results in the LAJTA Project indicate that the Common Quail is likely to occur in large-scale farming landscape, which can be classified as intensively managed agricultural environment. The importance of adequate vegetation structure (permanent, tall and dense) identified as protective rather than obstructive cover for farmland birds (e.g. Erdős et al. 2009, Eggers et al. 2011), has also been confirmed for Common Quail by our study.

\section{Acknowledgement}

This article was made in frame of the „EFOP-3.6.1-16-2016-00018-Improving the role of research+development+innovation in the higher education through institutional developments assisting intelligent specialization in Sopron and Szombathely". 


\section{References}

Aunins, A. \& Priednieks, J. 2003. Bird population changes in Latvian farmland, 1995-2000: responses to different scenarios of rural development. - Ornis Hungarica 12-13: 41-50.

Barthos, Gy. 1917. Adatok a fürj magassági elterjedéséhez [Data on the distribution of Quail]. - Aquila 24: 276. (in Hungarian)

Batáry, P. \& Báldi, A. 2004. Evidence of an edge effect on avian nest success. - Conservation Biology 18(2): 389-400. DOI: 10.1111/j.1523-1739.2004.00184.x

Batáry, P., Matthiesen, T. \& Tscharntke, T. 2010. Landscape-moderated importance of hedges in conserving farmland bird diversity of organic vs. conventional croplands and grasslands. - Biological Conservation 143: 2020-2027. DOI: 10.1016/j.biocon.2010.05.005

Báldi, A. 2008. Az agrárgazdálkodás változásának hatása madarakra: európai és hazai körkép [The effects of changes in agriculture on birds: a review for Europe and Hungary]. - Ornis Hungarica 15-16: 75-75.

Báldi, A. \& Batáry, P. 2011. The past and future of farmland birds in Hungary. - Bird Study 58(3): 365-377. DOI: $10.1080 / 00063657.2011 .588685$

Báldi, A. \& Faragó, S. 2007. Long-term changes of farmland game populations in a post-socialist country (Hungary). - Agriculture, Ecosystems and Environment 118(1-4): 307-311. DOI: 10.1016/j.agee.2006.05.021

Bán, T. \& Igmándy, J. 1939. Hajdúnánás fészkelő madarai [Breeding birds of Hajdúnánás]. - Aquila 42-45: 669-671. (in Hungarian)

BirdLife International 2018. Species factsheet: Coturnix coturnix. - Downloaded from http://www.birdlife. org on 30/09/2018.

Broyer, J. 1996. Les "fenaisons centrifuges", une méthode pour réduire la mortalité des jeunes râles de genêts Crex crex et des cailles des blés Coturnix coturnix [ «Centrifugal mowing», a method to reduce the mortality of young Corncrakes Crex crex and Common Quails Coturnix coturnix]. - Revue d'Écologie 51(3): 269-276. (in French)

Capdevila, J., Puigcerver, M., López, S., Pérez-Masdeu, E., García-Galea, E. \& Rodríguez-Teijeiro, J. D. 2016. The role of nest site selection and cereal production in differential nest predation in Common Quail Coturnix coturnix and hybrid quail C. coturnix x C. japonica. - Ibis 158(4): 784-795. DOI: 10.1111/ ibi.12390.

Chamberlain, D. E. \& Fuller, R. J. 2000. Local extinctions and changes in species richness of lowland farmland birds in England and Wales in relation to recent changes in agricultural land-use. - Agriculture, Ecosystems \& Environment 78(1): 1-17. DOI: 10.1016/S0167-8809(99)00105-X

Cohen, J. 1960. A coefficient of agreement for nominal scales. - Educational and Psychological Measurement 20: 37-46. DOI: $10.1177 / 001316446002000104$

Combreau, O. \& Guyomarc'h, J. C. 1989. Évolution de la sélectivité alimentaire chez la caille des blés captive en période estivale [Variation of food selectivity in captive Common Quail in summer]. - Cahiers d'Éthologie Appliquée 9(3): 321-338. (in French)

Combreau, O. \& Guyomarc'h, J. C. 1992. Energy intake, breeding success and growth in captive European Quail (Coturnix coturnix coturnix) in relation to diet. - Gibier Faune Sauvage 9: 677-692.

Cramp, S. (ed.) 1980. Handbook of the Birds of Europe, the Middle East and North Africa: The Birds of Western Palearctic, Vol. II. - Oxford University Press, pp. 496-503.

Debreceni, Ö., Drozd, A., György, I. \& Urbán, S. 1990. Áttelelő fürj (Coturnix coturnix) Jászkarajenő határában [Overwintering Quail at the border of Jászkarajenő]. - Madártani Tájékoztató júl-dec.: 25. (in Hungarian)

Donald, P. F., Green, R. E. \& Heath, M. F. 2001. Agricultural intensification and the collapse of Europe's farmland bird populations. - Proceedings of the Royal Society B 268(1462): 25-29. DOI: 10.1098/ rspb.2000.1325

Donald, P. F., Sanderson, F. J., Burfield, I. J. \& Van Bommel, F. P. J. 2006. Further evidence of continent-wide impacts of agricultural intensification on European farmland birds, 1990-2000. - Agriculture, Ecosystems \& Environment 116(3-4): 189-196. DOI: 10.1016/j.agee.2006.02.007

Eggers, S., Unell, M. \& Pärt, T. 2011. Autumn-sowing of cereals reduces breeding bird numbers in a heterogeneous agricultural landscape. - Biological Conservation 144: 1137-1144. DOI: 10.1016/j.biocon.2010.12.033

Erdős, S., Báldi, A. \& Batáry, P. 2009. Nest site selection and breeding ecology of Skylarks Alauda arvensis in Hungarian farmland. - Bird Study 56(2): 259-263. DOI: 10.1080/00063650902791983 
Faragó, S. 2002. Vadászati állattan [Hunting Zoology]. - Mezőgazda Kiadó, Budapest (in Hungarian)

Faragó, S. 2012a A Lajta project - Egy tartamos mezei vad és ökoszisztéma vizsgálat 20 éve [The Lajta Project - 20 years' long-term investigation of small game and agrarian ecosystems]. - Nyugat-magyarországi Egyetem Kiadó, Sopron (in Hungarian)

Faragó, S. 2012b Fürj - Coturnix coturnix [Common Quail - Coturnix coturnix]. - In: Faragó S. (ed.) Nyugat-Magyarország fészkelő madarainak elterjedési atlasza [Atlas of the breeding bird of Western Hungary]. - Nyugat-magyarországi Egyetemi Kiadó, Sopron, p. 57. (in Hungarian)

Faragó, S., Dittrich, G., Horváth-Hangya, K. \& Winkler, D. 2012. Twenty years of the Grey Partridge population in the LAJTA Project (Western Hungary). - Animal Biodiversity and Conservation 35(2): 311-319.

Fuller, R. (ed.) 2012. Birds and Habitat: Relationships in Changing Landscapes (Ecological Reviews). - Cambridge University Press, Cambridge DOI: 10.1017/CBO9781139021654

Gál, J. \& Marosán, M. 2003. Studies on the biometry, foraging- and reproductive biology of the Quail (Coturnix coturnix, Linnaeus 1758) in Hungary. - Acta Agronomica Óváriensis 50(2): 43-51.

George, K. 1990. Zu den Habitatansprüchen der Wachtel (Coturnix coturnix) [On the habitat requirements of the Common Quail (Coturnix coturnix)]. - Acta Ornithologica 2(2): 133-142. (in German)

George, K. 1996. Habitatnutzung und Bestandssituation der Wachtel (Coturnix coturnix) in Sachsen-Anhalt [Habitat use, density and population changes of Quail (Coturnix coturnix) in Sachsen-Anhalt, Germany]. - Vogelwelt 117: 205-211. (in German)

Glutz Von Blotzheim, U. N., Bauer, K. M. \& Bezzel, E. (eds.) 1994. Handbuch der Vögel Mitteleuropas. Band 5 [Handbook of the birds of Central Europe, Vol. 5.]. - Aula-Verlag GmbH, Wiesbaden

Green, R. E. \& Stowe, T. J. 1993. The decline of the Corncrake in Britain and Ireland in relation to habitat change. - Journal of Applied Ecology 30(4): 689-695. DOI: 10.2307/2404247

Guyomarc'h, J. C. 2003. Elements for a Common Quail (Coturnix c. coturnix) management plan. - Game and Wildlife Science 20: 1-92.

Guyomarc'h, J. C., Combreau, O., Pugicerver, M., Fontoura, P., Aebischer, N. J. \& Wallace, D. I. M. 1998. Coturnix coturnix Quail. - BWP Update 2: 27-46.

Hadarics, T. \& Zalai, T. 2008. Nomenclator Avium Hungariae [An annotated list of the birds of Hungary]. MME, Budapest, pp. 65-66. (in Hungarian and English)

Hall, L. S., Krausman, P. R. \& Morrison, M. L. 1997. The habitat concept and a plea for standard terminology. - Wildlife Society Bulletin 25(1): 173-182.

Hinsley, S. A. \& Bellamy, P. E. 2000. The influence of hedge structure, management and landscape context on the value of hedgerows to birds: a review. - Journal of Environmental Management 60(1): 33-49. DOI: 10.1006/jema.2000.0360

Holland, J., Smith, B., Birkett, T. \& Southway, S. 2012. Farmland bird invertebrate food provision in arable crops. - Annals of Applied Biology 160(1): 66-75. DOI: 10.1111/j.1744-7348.2011.00521.x

IBM Corp. Released, 2011. IBM SPSS Statistics for Windows, Version 20.0. - IBM Corp., Armonk, NY.

Jánoska, F. 1998. Fészkelő madárközösségek vizsgálata kisalföldi erdősávokban [Breeding bird communities of forest belts in the Kisalföld, Hungary]. - Ornis Hungarica 8(Suppl. 1): 49-58.

Keve, A. 1955. Külföldi gyűrűs madarak kézrekerülései. XVIII. gyűrüzési jelentés [Records of Birds ringed in abroad and found in Hungary. XVIII ${ }^{\text {th }}$ Report on Ringing]. - Aquila 59-62: 275-285. (in Hungarian)

Keve, A., Zsák, Z. \& Kaszab, Z. 1953. A fürj gazdasági jelentősége [The agricultural significance of the Quail]. - Természettudományi Évkönyv 4: 197-209. (in Hungarian)

Kovács, B. 1965. Adatok Hajdú-Bihar megye madárvilágához [Data on the avifauna of Hajdú-Bihar County]. - A Debreceni Déri Múzeum Évkönyve 1965: 363-381. (in Hungarian)

Kovács, G. 2005. Fürj (Coturnix coturnix) előfordulása vízi élőhelyeken [Occurrence of Common Quail (Coturnix coturnix) in wetlands]. - Aquila 112: 221. (in Hungarian)

Külley, J. 1924. Telelö fürj [Wintering Quail]. - Aquila 30-31: 301. (in Hungarian)

Landis, R. J. \& Koch, G. G. 1977. The measurement of observed agreement for categorical data. - Biometrics 33: $159-174$. DOI: $10.2307 / 2529310$

MME 2018. Magyarország madarai: Fürj [Birds of Hungary: Common Quail]. - http://www.mme.hu/magyarorszagmadarai/madaradatbazis-cotcot Downloaded: 2018-10-01 (in Hungarian)

McGowan, P. J. K., de Juana, E. \& Boesman, P. 1994. Common Quail (Coturnix coturnix). - In: del Hoyo, J., Elliott, A., Sargatal, J., Christie, D. A. \& de Juana, E. (eds.) Handbook of the Birds of the World, Vol. 2. Lynx Edicions, Barcelona, Spain, p. 509. 
Michailov, H. D. 1995. A study on the ecology and biology of Quail Coturnix coturnix (L. 1758) in the higher fields of western Bulgaria. - Thesis Summary of Dissertation, The Higher Institute of Forestry and Wood Technology, Department of Wildlife Management, Sofia

Moreby, S. J. \& Aebischer, N. J. 1992. Invertebrate abundance on cereal fields and set-aside land: implications for wild gamebird chicks. - British Crop Protection Council Monographs 50: 181-186.

Morelli, F. 2013. Relative importance of marginal vegetation (shrubs, hedgerows, isolated trees) surrogate of HNV farmland for bird species distribution in Central Italy. - Ecological Engineering 57: 261-266. DOI: 10.1016/j.ecoleng.2013.04.043

Morris, D. W. 1999. Has the ghost of competition passed? - Evolutionary Ecology Research 1: 3-20.

Morris, D. W. 2003. Toward an ecological synthesis: a case for habitat selection. - Oecologia 136(1): 1-13. DOI: $10.1007 / \mathrm{s} 00442-003-1241-4$

Morris, D. W. \& Davidson, D. L. 2000. Optimally foraging mice match patch use with habitat differences in fitness. - Ecology 81(8): 2061-2066. DOI: 10.2307/177095

Németh, T. M. \& Winkler, D. 2017. The impact of unmown refuge-strips on the breeding site fidelity of Common Quail (Coturnix coturnix) - a case study. - Hungarian Small Game Bulletin 13: 289-296. DOI: 10.17243/mavk.2017.289

Németh, T. M., Winkler, D. \& Faragó, S. 2014. The Common Quail (Coturnix coturnix Linnaeus, 1758) population of the Lajta Project during the period of 2013-2014. - Hungarian Small Game Bulletin 12: $125-134$. DOI: $10.17243 /$ mavk.2014.125

Panek, M. 1997. The effect of agricultural landscape structure on food resources and survival of Grey Partridge Perdix perdix chicks in Poland. - Journal of Applied Ecology 34(3): 787-792. DOI: 10.2307/2404923

Panek, M. 1998. Use of habitat by Common Quail (Coturnix coturnix) in western Poland. - In: Birkan, M., Smith, L. M., Aebischer, N. J., Purroy, F. J. \& Robertson, P. A. (eds.) Proceedings of the Perdix VII. Symposium on Partridges, Quails and Pheasants. - Gibier Faune Sauvage, Game \& Wildlife 15: 407-412.

Paton, P. W. 1994. The effect of edge on avian nest success: How strong is the evidence? - Conservation Biology 8: 17-26. DOI: 10.1046/j.1523-1739.1994.08010017.x

Perennou, C. 2009. European Union Management Plan 2009-2011, Common Quail, Coturnix coturnix. - European Commission, Brussels

Puigcerver, M., Rodriguez-Teijeiro, J. D. \& Gallego, S. 1999. The effects of rainfall on wild populations of Common Quail (Coturnix coturnix). - Journal für Ornithologie 140(3): 335-340. DOI: 10.1007/BF01651030

Puigcerver, M., Vinyoles, D. \& Rodríguez-Teijeiro, J. D. 2007. Does restocking with Japanese quail or hybrids affect native populations of Common Quail Coturnix coturnix? - Biological Conservation 136(4): 628635. DOI: 10.1016/j.biocon.2007.01.007

Rands, M. R. W. 1986. Effect of hedgerow characteristics on partridge breeding densities. - Journal of Applied Ecology 23(2): 479-487. DOI: 10.2307/2404030

Rapos, P. 1957. Fürj késői költése [Late breeding of Quail]. - Aquila 63-64: 276. (in Hungarian)

Rodríguez-Teijeiro, J. D., Sardà-Palomera, F., Alves, I., Bay, Y., Beça, A., Blanchy, B., Borgogne, B., Bourgeon, B., Colaço, P., Gleize, J., Guerreiro, A., Maghnouj, M., Rieutort, C., Roux, D. \& Puigcerver, M. 2010. Monitoring and management of Common Quail Coturnix coturnix populations in their atlantic distribution area. - Ardeola 57: 135-144.

Rosenzweig, M. L. 1981. A theory of habitat selection. - Ecology 62(2): 327-335. DOI: 10.2307/1936707

Saint-Jalme, M. \& Guyomarc'h, J. C. 1989. Recent changes in population dynamics of European Quail in the western part of its breeding range. - In: Myrberget, S. (ed.) Transactions of the XIX ${ }^{\text {th }}$ Congress of the International Union Game Biologists. Norwegian Institute for Nature Research, Trondheim, Norway, pp. $130-135$.

SAS Institute Inc. 2012. JMP Version 10.0. - SAS Institute Inc, Cary, NC.

Szép, T., Nagy, K., Nagy, Zs. \& Halmos, G. 2012. Population trends of common breeding and wintering birds in Hungary, decline of long-distance migrant and farmland birds during 1999-2012. - Ornis Hungarica 20(2): 13-63. DOI: 10.2478/orhu-2013-0007

Szüts, B. 1898. Fürj januáriusban Szatmár-vármegyében [January Occurrence of Quail in Szatmár county]. Természettudományi Közlöny 30(343): 165. (in Hungarian)

Tryjanowski, P., Hartel, T., Báldi, A., Szymański, P., Tobolka, M., Herzon, I., Goławski, A., Konvička, M., Hromada, M., Jerzak, L., Kujawa, K., Lenda, M., Orłowski, G., Panek, M., Skórka, P., Sparks, T., Tworek, S., Wuczyński, A. \& Żmihorski, M. 2011. Conservation of farmland birds faces different challenges in Western and Central-Eastern Europe. - Acta Ornithologica 46(1): 1-12. DOI: 10.3161/000164511X589857 
Udvardy, M. 1941. A Hortobágy madárvilága [Birds of Hortobágy]. - Tisia 5: 92-169. (in Hungarian)

Vickery, J., Carter, N. \& Fuller, R. J. 2002. The potential value of managed cereal field margins as foraging habitats for farmland birds in the UK. - Agriculture, Ecosystems \& Environment 89(1-2): 41-52. DOI: 10.1016/S0167-8809(01)00317-6

Vořǐšek, P., Jiguet, F., van Strien, A., Škorpilová, J., Klvanová, A. \& Gregory, R. D. 2010. Trends in abundance and biomass of widespread European farmland birds: How much have we lost? - BOU Proceedings - Lowland Farmland Birds III. pp. 1-24.

Wilson, J. D., Morris, A. J., Arroyo, B. E., Clark, S. C. \& Bradbury, R. B. 1999. A review of the abundance and diversity of invertebrate and plant foods of granivorous birds in northern Europe in relation to agricultural change. - Agriculture, Ecosystems \& Environment 70(1-2): 13-20. DOI: 10.1016/S01678809(99)00064-X

Wretenberg, J., Lindström, A., Svensson, S., Thierfelder, T. \& Part, T. 2006. Population trends of farmland birds in Sweden and England: similar trends but different patterns of agricultural intensification. - Journal of Applied Ecology 43(6): 1110-1120. DOI: 10.1111/j.1365-2664.2006.01216.x

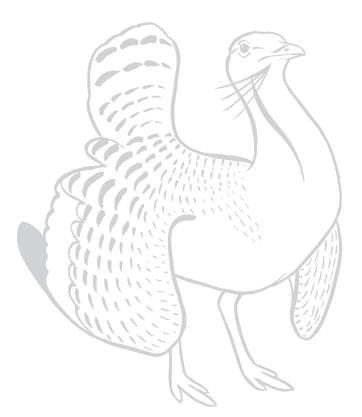

